было принято решение разработки более уточненного механизма расчета налога и определения кадастровой стоимости недвижимости, которая обязана быть сбалансирована с реальной рыночной стоимостью.

Законодательная инициатива реализовалась в новой редакции федерального закона «О государственной кадастровой оценке», которая предполагает применение единого подхода кадастровой оценки, что приведет к уменьшению бесконтрольных действий посредством ограничения правовыми рамками, а значит и спаду исков о пересмотре кадастровой стоимости.[1]

Функции независимых оценщиков перейдут государственным бюджетным учреждениям, и полномочия определения кадастровой стоимости будут носить постоянный характер. Такие полномочия могут быть выделены уже существующим учреждениям либо будут образованы новые, в зависимости от воли органов региональной власти, которые и будут нести ответственность за исполняемую работу.

В новом законе особую роль носит федеральный государственный надзор за проведением государственной кадастровой оценки. Исполняющим эту роль назначен Росреестр. Кроме осуществления контроля, в его обязанности будет входить и обеспечение процесса предостережения от ошибок, которое будет реализовано в качестве постоянного наблюдения за осуществлением процедуры оценки кадастровой стоимости. По прежнему остаётся актуален Единый государственный реестр недвижимости. Именно он и является прямым воплощением деятельности всего механизма.

Процедура оспаривания результатов определения кадастровой стоимости также будет включать рассмотрение этих дел в суде или в комиссиях по рассмотрению споров, которые будут созданы уполномоченным органом субъекта РФ.

Стоит заметить, что законодатель не стал поспешно вводить новый проект, а постепенно и разумно определил процесс переходного периода до
2020 года, в течение возможно использования и старого и нового порядка оценки.

В заключение хотелось бы сказать о том, что процедура оценки кадастровой недвижимости давно требовала обновления и внесения законодательной инициативы. По причине множественных правовых пробелов данная сферы оказалась подвержена бесконтрольности, обернувшейся множественными разбирательствами, осаждавшими и отягчающими судебную систему страны. Также огромные убытки нес экономический рынок, «лихорадка» которого отражалась и на социальном настроении всего общества. Жесткие меры и всепоглощающий контроль органов государственной власти стали наилучшей альтернативой, способной нормализовать и стабилизировать рынок, посредством введения органа надзора. Данные шаги являются проявлением функции защиты, которая помогает избавить государство от такого явления как государственные риски, так как именно опасность их возникновения вынуждает власть переходить к наиболее строгим подходам для того, чтобы обезопасить население государства

\section{Литература}

1. Федеральный закон от 03.07.2016 N 237-Ф3 (ред. от 29.07.2017) "О государственной кадастровой оценке"// СПС КонсультантПлюс (дата обращения 20.04.2019 г.)

2. Постановление Правительства РФ от 08.04.2000 N 316 (ред. от 30.06.2010) "Об утверждении Правил проведения государственной кадастровой оценки земель" // СПС «КонсультантПлюс» (дата обращения 20.04.2019 г.)

3. Обобщенные сведения о рассмотрении споров о результатах определения кадастровой стоимости в судах. Росреестр. Федеральная служба государственной регистрации, кадастра и картографии $\begin{array}{llll}\text { (дата обращения } & \text { 20.04.2019 }\end{array}$ https://rosreestr.ru/site/activity/informatsiya-osudebnykh-sporakh-v-otnoshenii-rezultatovopredeleniya-kadastrovoy-stoimosti-obektov-/

\title{
ПОНЯТИЕ И РАЗВИТИЕ ПРАВ ЧЕЛОВЕКА
}

\author{
Жирикова Элина Исламовна \\ магистрант 2 года обучения по программе \\ «Конституционное право; муниципальное право», \\ направление - 40.04.01 «Юриспруденция», \\ Институт права, экономики и финансов \\ Кабардино-Балкарского государственного университета им. Х. М. Бербекова \\ DOI: $10.31618 /$ ESU.2413-9335.2019.8.61.67
}

\section{АННОТАЦИЯ}

В настоящей статье рассматриваются понятие прав человека и основные подходы к определению его содержания. Также дается обзор развития самого термина в правовой и общественной мысли. При анализе используются такие методы как исторический и сравнительно-правовой. Результат и выводы исследования могут быть использованы в теории права для дальнейшего развития понятийно-категориального аппарата и объяснения природы прав человека.

ABSTRACT.

This article discusses the concept of human rights and the main approaches to the definition of its content. It also views the development of the term itself in legal and public thought. The analysis uses such methods as 
historical and legal comparison. The results and conclusions of the study can be used in the theory of law for the further development of the conceptual and categorical apparatus and the explanation of the nature of human rights.

Ключевые слова: права человека, свободы человека, естественные права, концепции прав человека. Keywords: human rights, human freedoms, natural rights, human rights concepts.

Права человека в условиях современного мира являются важнейшей ценностью и выступают главным критерием любого правового государства. Все изменения, происходящие как на государственной арене, так и в самом обществе, отражаются и на проблемах прав человека.

Права человека - универсальная категория, представляющая человеку возможность пользоваться благами и условиями безопасного, свободного существования в обществе и государстве. Права человека вытекают из самой природы человека. Они возникают и развиваются с учетом постоянно изменяющихся условий жизни общества, складываются объективно и не зависят от государственного признания, принадлежат человеку от рождения, имеют неотчуждаемый, неотъемлемый характер, признаются естественными, непосредственно действующими. Признание прав человека, их соблюдение и защита являются обязанностью каждого государства.

Историю становления и развития прав человека условно можно представить в виде таких сменяющих друг друга процессов, как зарождение самой идеи и формирование учений о правах человека, закрепление прав человека как системного образования, их социализация, интернационализация и глобализация.

В науке существует ряд концепций о правах человека, среди них: естественно-правовая, позитивистская, социалистическая, теологическая и универсальная.

Естественно-правовая концепция прав человека в своей основе опирается на то, что права человека являются выражением свободы выбора и действий человека. Свобода дается человеку Богом, и никто не вправе посягать на нее. В римский период понятие прав человека было применимо только к свободным гражданам. Здесь можно выделить труды таких мыслителей, как Сенека, Цицерон и др. [1, с. 274]. С введением понятий «субъект права» и «равенство всех перед законом» права человека получили еще большее развитие.

Как юридическое явление права человека впервые появились в VI-VIII вв. у западных народов, а затем (с конца XIX в. до начала XX в.) они начали появляться и в других странах. Предпосылкой их появления послужило развитие частной собственности, ее обособление от власти, развитие демократии как регулятора общественных отношений и социализация личности.

C XIII в. для определенных слоев общества (феодалов и дворян), начали появляться законы, затрагивающие защиту их прав. Первое документальное закрепление концепция прав человека получила с принятием в 1215 году Великой Хартии вольностей [2], в соответствии с которой любой человек имел право свободно распоряжаться собой, правосудие единолично закрепилось в руках суда, а личность была наделена правом на неприкосновенность. В связи с сословным делением в эпоху Средневековья возникла иерархичность права. С этого времени обладание каким-либо правом зависело от принадлежности к определенному сословию.

Наибольшего расцвета естественно-правовая концепция получает в эпоху Возрождения. Здесь необходимо отметить труды таких мыслителей, как Ж.-Ж. Руссо, Дж. Локк, Ш.Л. Монтескье, Г. Гроций [3, с. 24], И. Кант [с. 302], которые критиковали существующий строй и обосновывали концепцию, в которой главное место отводилось правам и свободам личности.В период с XVI в. по XVIII в. были провозглашены права человека в вопросах религии, которая в то время в жизни как отдельно взятого человека, так и всего общества и играла первостепенную роль. Именно равноправие людей в вопросах вероисповедания легло в основу принципа равенства всех перед законом. Этот период сыграл важную роль в борьбе за права человека в политической, гражданской, уголовной и других сферах общественной жизни, связанных с возникновением органов законодательной и представительной власти.

Появление основных школ естественного права способствовало тому, что они стали основой таких важнейших документов, как: Билль о правах в Англии, Петиция о правах, Декларация о правах Вирджинии, Декларация независимости и Билль о правах, Декларация прав человека и гражданина во Франции. В этих документах было раскрыто понятие и сущность прав человека, впервые они были объявлены в качестве неотъемлемых, а также была определена роль государства в установлении статуса личности в гражданском обществе.

К функциям государства была отнесена защита прав на безопасность, свободу, собственность, сопротивление угнетению. Свобода выражения мыслей и слова подчеркивалась в качестве важнейшего права человека. Однако, как отмечалось, права и свободы одного человека не должны были наносить вреда другому человеку, а гарантом соблюдения прав признавалось государство.

Для дальнейшего развития концепции прав человека из всех перечисленных выше документов Декларация прав человека [5] сыграла наибольшую роль. Положения этой декларации легли в основу законодательства большинства западноевропейских государств. В ней были закреплены такие важнейшие принципы правового государства, как верховенство закона, подотчетность всех органов и должностных лиц, представительная форма управления.

Период со второй половины XIX века по вторую половину XX века характеризуются окончательным признанием прав человека как высшей ценности.

Однако стоит отметить тот факт, что естественно-правовая доктрина является не единственной в определении взаимоотношений государства и личности. Ее альтернативой выступает позитивистская доктрина, в соответствии с которой права человека, их содержание и объем определяются государством. Минусом естественной концепции прав 
человека основоположники считали факт отсутствия единой системы прав и свобод человека, что впоследствии, по их мнению, подрывало веру в права человека и приводило к анархии. Только нормативные правовые акты, принятые государством, могут быть единственным основанием и источником прав человека.

Идеологическая борьба этих двух доктрин, в результате которой и возник унифицированный международный стандарт прав человека, продолжалась вплоть до второй половины XX века.

Стимулом к возникновению социалистической концепции прав человека послужило имущественное расслоение общества и ухудшение положения трудящихся. Последователи этой концепции отрицали универсальность прав человека, а в качестве важнейшего принципа при закреплении прав и свобод провозглашали классовый подход, государственные интересы имели приоритет перед интересами личности.

Теологическая концепция прав человека, основывающаяся на религиозных учениях, основывается на том, что права человека имеют божественное происхождение, которое ставит обязательным условием неукоснительное соблюдение условий веры. Проводя сравнительную характеристику с остальными концепциями прав человека, можно утверждать, что теологическая концепция находится на стыке между естественно-правовой и позитивистской.

Универсальная концепция прав человека ввела новое понимание прав человека. Ее суть заключается в том, что права человека из внутригосударственных проблем переросли в общемировые. Главный постулат этой концепции - права человека носят всеобщий, универсальный характер. Однако данная концепция часто подвергается критике в связи с тем, что она не учитывает исторические, религиозные, культурные и региональные особенности, а потому не органична для других культур и цивилизаций. На основании этого в науке возникает релятивизм в познании прав человека, т.е. отрицание универсальности прав человека.

На основании перечисленных концепций в науке прав человека обозначилось несколько подходов к пониманию прав человека: нормативистский, ценностный и универсальный. Нормативистский подход базируется на правовых нормах и правовых отношениях, ценностный определяет права и свободы человека как высшую ценность, а универсальный устанавливает, что права человека являются всеобщим явлением, т.е. в него входят не только юридические, но и экономические, социальные, политические, культурные и иные факторы, которые оказывают влияние на содержание прав и свобод человека.

В России теория прав и свобод человека является более скудной. С принятием Русской Правды в Древней Киевской Руси получило закрепление признание закона в качестве основного регулятора в обществе, призванного обеспечить высшую ценность человеческой жизни. Были провозглашены такие понятия, как личная безопасность и неотъемлемость собственности. Появление же первых прав и свобод человека в России начинается с XVIII в. С конца XIX в. - начала XX в. в отечественной науке признавалась недопустимость вмешательства государства в частную жизнь.

Наиболее значимые изменения в подходе к правам человека произошли в период существования СССР. В конституциях советского периода социально-экономические права обладали приоритетом над естественными и неотъемлемыми правами человека. Такие права, как свобода слова, печати, митингов, собраний и демонстраций, были зафиксированы только формально, а право на частную собственность и право на свободу передвижения и вовсе не получили законодательного закрепления.

Однако, несмотря на это, нельзя умалять роль СССР в создании международно-правовых стандартов прав человека. В 1947-1948 гг. в подготовке проекта Всеобщей Декларации прав человека активное участие принимали и советские представители.

В связи с тем, что отечественная научная доктрина продолжала критически оценивать многие положения концепции прав человека, до второй половины XX века в этой сфере не было масштабных исследований. В последующем из-за протекавших реформ и давления мировой общественности на политическое руководство СССР проблемы прав человека стали предметом изучения таких отечественных ученых, как Н.В. Витрук [6, с. 692] В.Д. Зорькин [7], В.Н. Карташов [8], Н.И. Матузов [9], Л.Д. Воеводин [10, с. 9] и многие другие.

Таким образом, необходимо отметить, что существующие концепции и подходы к пониманию прав человека стали фундаментом для современного понимания прав человека. Все они в совокупности способствовали формированию таких основных положения, на которых базируется современное понимание прав человека: власть в государстве действует в определенных законом пределах, каждый человек обладает автономностью, в которую не может вторгнуться никакая сила, а также каждый человек обладает средствами и механизмами действий против государства с целью защиты своих прав.

\section{Список литературы:}

1. Нерсесянц В.С. Права человека в истории политической и правовой мысли / Права человека в истории человечества и в современном мире. М.: 1989. - 147 c.

2. Крашенинникова Н.А. Великая Хартия вольностей 1215 г. // Большая российская энциклопедия. [Электронный https://bigenc.ru/law/text/1904753

3. Геворкян М.В. Истоки разделения властей // Вестник Псковского государственного университета. Серия: Социально-гуманитарные и психолого-педагогические науки. 2010. №11. - 131 с.

4. Кант И. К вечному миру. Соч. Т.6. - М.: 1966. - $743 \mathrm{c}$.

5. Лабутина Т.Л., Чиркин В. Е. Декларация прав человека и гражданина 1789 г. // Большая российская энциклопедия. [Электронный ресурс]: https://bigenc.ru/law/text/1866147

6. Витрук Н.В. Конституционное правосудие. Судебно-конституционное право и процесс: учеб. пособие. 4-е изд., перераб. и доп. / Н.В. Витрук. М.: Норма: Инфра-М, 2012. - 592 с. 
7. Зорькин В.Д. Конституция и права человека в XXI веке. К 15-летию Конституции Российской Федерации и 60-летию Всеобщей декларации прав человека. М.: Норма, 2008. - 224 с.

8. Карташов, В.Н. Теория правовой системы общества: учебник для бакалавриата и магистратуры / В.Н. Карташов. - М.: Издательство Юрайт, 2018. - 283 c

УДК 34
9. Матузов Н.И. Личность. Права. Демократия. - Саратов, 1972. - 292 с.

10. Воеводин Л.Д. Система конституционных прав советских граждан // Юридические гарантии конституционных прав и свобод личности в социалистическом обществе.- М.: 1987. - 116 с.

\title{
ПРОЦЕСС ОСУЩЕСТВЛЕНИЯ ЛИЦЕНЗИРОВАНИЯ ПРОИЗВОДСТВА ПАРФЮМЕРНОЙ
} ПРОДУКЦИИ

\author{
Лочкарев Андрей Викторович \\ к.ю.н., доцент кафедры гражданского и арбитражного процесса, г.Самара \\ Зотова Ангелина \\ Студентка 2 курса, факультет «Юриспрудениия» \\ Самарский Государственньй Экономический Университет \\ Россия, г. Самара
}

\section{АННОТАЦИЯ.}

В статье проводится анализ процесса осуществления лицензирования производства парфюмерной продукции. Автором доказывается необходимость совершенствования законодательства в сфере административного лицензирования в Российской Федерации. Методология исследования - анализ научной литературы по заданной теме, а также практического опыта по данной проблеме.

\section{ANNOTATION.}

The article analyzes the process implementation licensing perfume products. The author proves the need to improve legislation in the field of administrative licensing in the Russian Federation. The research methodology is the analysis of scientific literature on a given topic, as well as practical experience on this issue.

Ключевые слова: парфюмерия, раствор, этиловый спирт, фальсификат, лицензирование

Key words: perfumery, solution, ethyl alcohol, counterfeit, licensing.

Парфюмерия - совокупность смесей ароматизированной композиции, предназначенной для придания определенного запаха. По причине состава раствора стоит отметить специфичность данной категории продукции, что в свою очередь вызывает вопросы относительно возможности правового регулирования и контроля за этой продукцией на рынке. Объясняется это тем, что состав содержит в обязательной основе спирт или спиртованную основу.

Вся парфюмерия, в соответствии со стандартами делится на несколько видов: духи, одеколоны, парфюмерные воды, туалетные воды, душистые воды. В зависимости от вида также различается и концентрация спиртовой основы в растворе. Самым концентрированным продуктом являются духи, доля спиртовой основы в которой может достигать 85\% (концетрированные - 55\%, группа «экстра»- 70\%, классические духи- 85\%), следом за ними следуют парфюмерная вода и туалетная вода - 75\% , далее одеколон, содержащий $60 \%$ и душистая вода соответственно - 20\%. В итоге мы видим, что большая часть состава предмета, исключая душистую воду, содержит именно то сырье, которое и подлежит контролю. Закон не устанавливал обязательство в получении какой-либо лицензии или разрешения на ведение предпринимательской деятельности в сферах производства и реализации парфюмерной продукции, содержащей этиловый спирт и прошедший государственную регистрацию в уполномоченных федеральных органах исполнительной власти. [1]

В прошлом государственная регистрация данной категории продукции осуществлялась на основании приказа министерства здравоохранения России, однако он утратил силу в соответствии с приказом этого же органа, а в настоящее время нормативно-правовых актов, заменяющий этот документ не существует. [2] Однако существует система государственной регистрации в соответсвии с нормами, введенными решением Комиссии Таможенного союза, которые отчасти контролируют производство парфюмерной продукции, на основании технического регламента.

Для регулирования этой сферы, а точнее для борьбы с нелегальными производителями, министерство финансов решило внести на рассмотрение в правительство законопроект о взимании акциза с производителей данной категории продукции. Этот барьер позволит фильтровать подлинные и качественные товары от фальсификата. Приобретение этилового спирта будет облагаться акцизом наибольшей стоимостью в 523 рубля за литр будет вычисляться за безводный спирт, а при денатурированном его коэффициент опуститься до 107 рублей соответственно. При этом данная система защищает порядочных изготовителем продукции, которые смогут получить налоговый возврат после документального подтверждения факта реализации спирта посредством изготовления парфюмерно- 